Acta Universitatis Wratislaviensis • No 3982

Literatura i Kultura Popularna XXV, Wrocław 2019

https://doi.org/10.19195/0867-7441.25.15

\author{
Jarosław Woźniak \\ ORCID: 0000-0001-7648-1427 \\ Uniwersytet Wrocławski
}

\title{
Życie po życiu albo republika bytów. Starość aksolotla Jacka Dukaja w perspektywie ekokrytycznej*
}

Słowa kluczowe: posthumanizm, asamblaż, płaska ontologia, teoria aktora-sieci, science fiction, ekokrytyka

Keywords: posthumanism, assemblage, flat ontology, Actor-Network Theory, science-fiction, ecocriticism

[K]ażda interpretacja musi z konieczności stosować przemoc [...].

M. Heidegger, Kant a problem metafizyki

Dowieść w tym obszarze niepodobna niczego, ale wskazać można niejedno [...].

M. Heidegger, Identyczność i różnica

But what else would one expect when consorting with metaphysicians?

I. Bogost, Alien Phenomenology

* Niniejszy artykuł stanowi rozszerzoną wersję referatu przedstawionego na konferencji „Literatura i Kultura Popularna (VI)" w Wiśle, która odbyła się w czerwcu 2017 roku. Od tego czasu pojawiło się w polskim dyskursie kilka publikacji poruszających podobne tematy. Najważniejsze z nich to: Poetyki ekocydu. Historia, natura, konflikt, red. A. Ubertowska, D. Korczyńska-Partyka, E. Kuliś, Warszawa 2019; A. Barcz, Przedmioty ekozagłady. Spekulatywna teoria hiperobiektów Timothy'ego Mortona i jej (możliwe) ślady w literaturze, „Teksty Drugie” 2018, nr 2; A. Marzec, „Jesteśmy połaczonym ze soba światem” - Timothy Morton i widmo innej wspólnoty, „Teksty Drugie” 2018, nr 2; K. Abriszewski, Czy Teoria Aktora-Sieci daje narzędzia do ekokrytyki?, „Teksty 
W niniejszym artykule chciałbym podjąć próbę ekokrytycznej lektury Starości aksolotla (wydanie elektroniczne, na którym opierałem się, pisząc artykuł, pochodzi z 2015 roku, natomiast w 2019 roku utwór ukazał się drukiem) ${ }^{1}$ Jacka Dukaja, wychodzącej jednak poza tradycyjne ramy teoretyczne wytyczane w ekokrytyce. Takie odczytanie utworu wymaga przyjęcia pewnych nieoczywistych założeń teoretycznych oraz odrzucenia innych, prowadzących do być może wyraźniejszych interpretacji. Na przykład bez większego problemu można by odnieść do tego utworu rozpoznania poczynione przez Grzegorza Robaczewskiego ${ }^{2}$, który wpisał twórczość Dukaja w nurt gnostycyzmu, a dokładniej współczesnej techgnozy $^{3}$, rozumianej jako - jak kilka lat później pisał Krzysztof Uniłowski mistyczna interpretacja nauki i techniki, oparta na transhumanistycznej idei ewolucji ludzkości w formę czysto informacyjną ${ }^{4}$. Oczywiście pojawiają się drobne przesunięcia i zmiany akcentów, jednak główny motyw pozostaje zasadniczo bez większych zmian. Znów powracają kwestie włączenia jednostki w postludzką sieć i ewolucyjnego determinizmu, wchodzące w konflikt z silnie zakorzenionym w naszej kulturze indywidualizmem i przekonaniem o jednostkowości bytów ${ }^{5}$. W omawianym opowiadaniu pojawiają się także inne charakterystyczne dla twórczości Dukaja elementy, na przykład budowanie struktur społecznych i systemów politycznych — przykłady zamiłowania pisarza do takich niuansów można znaleźć między innymi w Lodzie (2007), Czarnych oceanach (2001) czy Perfekcyjnej niedoskonałości (2004). Oczywistość i typowość pewnych wątków sprawiają, że muszą one pozostać poza obrębem zagadnień, jakie chciałbym tutaj poruszyć. Łatwo podążyć także humanistycznym tropem i wykazać, że autor znów poszukuje istoty człowieczeństwa. Piszę o tym we wstępie, ponieważ opowiadanie Jacka Dukaja skłania raczej do interpretacji zgoła odmiennych ${ }^{6}$ od tej, którą prezentuję w niniejszym opracowaniu.

Drugie" 2018, nr 2; A.W. Nowak, Wyobraźnia ontologiczna. Filozoficzna (re)konstrukcja fronetycznych nauk społecznych, Warszawa 2016.

1 J. Dukaj, Starość aksolotla, b.m., 2015, e-book; wersja papierowa: idem, Starość aksolotla, Kraków 2019. Lokalizacja cytatów podana według systemu numeracyjnego zastosowanego w formacie EPUB.

2 Zob. G. Robaczewski, Odczytywanie światów Jacka Dukaja. „Esensja” 2004, nr 1, https:// esensja.pl/ksiazka/publicystyka/tekst.html?id=326 (dostęp: 5.09.2016).

3 Zob. E. Davis, TechGnoza. Mit magia + mistycyzm w wieku informacji, Poznań 2002.

${ }^{4}$ Zob. K. Uniłowski, Lord Dukaj albo fantasta wobec mainstreamu, „FA-art.” 2007, nr 4, s. 40.

5 Zob. ibidem.

${ }^{6}$ O melancholijnym wymiarze opowiadania Dukaja pisał już Grzegorz Jankowicz w szkicu Smutek robotów (zob. idem, Smutek robotów (Jacek Dukaj), [w:] idem, Uchodźcy z ziemi Urlo. Eseje, Kraków 2015, s. 227-232), dlatego aby uniknąć redundancji, pozwolę sobie nie rozwijać tego wątku. Nie podejmę również transhumanistycznych tematów ani cybernetycznej problematyki, choć temat ten pojawia się u Dukaja nad wyraz często. Odniosę się tylko pokrótce do kwestii cielesności, poświęcając jej ten krótki akapit. Oderwanie człowieka od ciała i wydestylowanie „esencji-informacji” zdaje się mieć w Starości aksolotla znacznie bardziej ponure konsekwencje niż na przykład w Perfekcyjnej niedoskonatości, w której to powieści główny bohater, Adam Zamoyski, 
Poza przeprowadzeniem ekokrytycznej interpretacji Starości aksolotla chciałbym również podjąć się przemyślenia możliwej drogi dla (futurystycznej) ekokrytyki — z tego powodu czytelnik może mieć wrażenie, że utwór Dukaja schodzi na dalszy plan w moich rozważaniach, co nie do końca będzie niezgodne z prawdą. Poruszać się będę w obrębie materialistycznej ekokrytyki, opartej na nowych materializmach, reprezentowanej przez Serpil Oppermann, Serenellę Iovino, a także Timothy' ego Mortona, którego projekt to jednak osobne zjawisko ${ }^{7}$. Jedną z podstawowych idei jest tutaj przypisanie materii kategorii sprawczości (co oczywiście stoi w opozycji do wizji kojarzącej sprawczość z intencjonalnością, a więc głównie z ludzką inteligencją), a także traktowanie poststrukturali-

samodzielnie podejmuje decyzję o wejściu na drogę „technologicznej ewolucji” i przejściu w wymiar wirtualny. Jeżeli we wcześniejszym dziele Dukaja kwestia cielesności i jej utraty nie grała tak znacznej roli, to Starość aksolotla uderza w ton sceptycyzmu wobec ewolucji poza ciałem. Kwestię tę, jak sądzę, przed laty doskonale nakreślił Stanisław Lem, którego słowa pozwolę sobie obszernie zacytować, gdyż zdają się doskonale podsumowywać problematykę cielesności wyłaniającą się z opowiadania Dukaja: „nie chodzi nam jedynie o wąsko rozumiane przywiązanie człowieka do takiego ciała, jakie posiada. Cielesnością, w kształtach i wyrazie, daną nam przez Naturę, wypełniona jest cała kultura i sztuka wraz z najbardziej abstrakcyjnymi teoriami. Cielesność ukształtowała kanony wszystkich historycznych estetyk, wszystkie istniejące języki, a przez to i całość myślenia ludzkiego. Cielesny jest przecież nasz duch; nieprzypadkowo to słowo wywodzi się z oddychania. Wbrew pozorom nie ma też wartości, które powstałyby bez udziału czynnika cielesnego. [...] Gdyby człowiek naprawdę miał sam siebie przekształcić pod naciskiem wytworzonych własnymi rękami technologii, gdyby miał za swego następcę uznać robota z doskonałym mózgiem krystalicznym, byłoby to największym jego szaleństwem. Oznaczałoby to ni mniej, ni więcej, jak tylko fakt zbiorowego samobójstwa rasy, przysłonięty pozorem jej kontynuacji w maszynach myślących, które stanowią część wytworzonej technologii: tak zatem człowiek w ostatecznej konsekwencji dopuściłby do tego, aby urzeczywistniona przezeń technologia wyparła go z miejsca, w którym istniał, z jego ekologicznej niszy" - idem, Summa technologiae, Warszawa 2010, s. 337. Pominę również tematy kartezjańskie. Pozwolę sobie tylko na marginesie zauważyć, że wydźwięk opowiadania Dukaja harmonizuje się w pewien sposób z tezami autora Błędu Kartezjusza i W poszukiwaniu Spinozy, sugerując co chwila niemożliwość doskonałego skopiowania świadomości. Z tymi zagadnieniami wiążą się także kwestie ewolucji i technoewolucji ludzkości, ewolucyjnego determinizmu i problem humanistycznego przywiązania do idei jednostkowości istnienia, na co zwracał uwagę Krzysztof Uniłowski (idem, op. cit., s. 40).

${ }^{7}$ W ekofilozoficznej debacie na temat materialności za najważniejsze można uznać następujące publikacje: K. Barad, Meeting the Universe Halfway: Quantum Physics and the Entanglement of Matter and Meaning, London 2007; A. Pickering, The Mangle of Practice. Time, Agency, and Science, Chicago 1995; J. Bennett, The Enchantment of Modern Life: Attachments, Crossings, and Ethics, New York 2001; J. Rouse, How Scientific Practices Matter: Reclaiming Philosophical Naturalism, Chicago 2002; F. Mathews, For Love of Matter: A Contemporary Panpsychism, New York 2003; D. Coole, S. Frost, New Materialisms: Ontology, Agency, and Politics, London 2010; S. Alaimo, Bodily Natures Science, Environment, and the Material Self, Bloomington 2010; J. Bennett, Vibrant Matter. A Political Ecology of Things, London 2010; S. Hekman, The Material of Knowledge Feminist Disclosures, Bloomington 2010; D. Abram, Becoming Animal: An Earthly Cosmology, New York 2010; V. Kirby, Quantum Anthropologies: Life at Large, London 2011; S. Iovino, S. Oppermann, Material Ecocriticism, Bloomington 2014. 
stycznych koncepcji językowego konstruowania rzeczywistości jako dziedzictwa, które należy przyjąć, ale też przezwyciężyć.

Punkty orientacyjne będą dla mnie stanowić koncepcje autorów związanych w pewien sposób z „,nowymi materializmami”: Jane Bennett, Iana Bogosta, Grahama Harmana, Timothy'ego Mortona, Brunona Latoura i — już osobno - Bernarda Stieglera. Do pism Bennett sięgam ze względu na jej rozważania na temat życia materii nieożywionej, zamieszczone w pracy Vibrant Matter: A Political Ecology of Things (2010). Również Bogost w książce Alien Phenomenology, or What It's Like to Be a Thing (2012) w centrum uwagi stawia przedmioty, rzeczy — obcych, z którymi stykamy się na co dzień; badacz rozwija specyficzną fenomenologię opartą na object-oriented ontology $(\mathrm{OOO})^{8}$, z której będę jednak korzystał właściwie w niewielkim stopniu, gdyż nie o fenomenologię mi chodzi. Z pism Harmana wolałbym zaczerpnąć raczej elementy inspirowane myślą Brunona Latoura niż Heideggera ${ }^{9}$, choć nieraz trudno je odseparować. Dlatego też Harman częściej będzie występować jako oryginalny przewodnik po metafizyce Latoura niż autor Traktatu o przedmiotach (2011, wyd. pol. 2013). Timothy Morton zaś, jako jedyny (choć nietypowy) przedstawiciel krytyki ekologicznej w tym gronie, przeprowadzi mnie przez chwiejny most ekologii bez natury (ecology without nature) na terytorium zajmowane przez dziwaczną ekologię (queer ecology — choć Morton w swoim projekcie nawiązuje do queer theory, pozwalam sobie termin przetłumaczyć właśnie w taki sposób, gdyż taki dobór słów dobrze charakteryzuje projekt tego badacza, który przecież nie ogranicza się do ram wyznaczanych queer theory, a jedynie czerpie z niej antyfundacjonalistyczne inspiracje).

8 Termin ten został przełożony przez Wojciecha Małeckiego jako „obiektowa ontologia”, co zachowuje chwytliwą aliterację i estetyczny skrót (OO), w przeciwieństwie do dość topornego pojęcia „ontologii zorientowanej na przedmiot”; zob. idem, Rzeczy maja glos: realizm spekulatywny i literaturoznawstwo, [w:] Wspótczesne dyskursy konfliktu. Literatura - język - kultura, red. W. Bolecki, W. Soliński, M. Gorczyński, Warszawa 2015, s. 265-283. W dalszej części artykułu właśnie tego thumaczenia będę używał. Być może warto zaznaczyć, że termin ten pochodzi — pośrednio - z pism Grahama Harmana, a konkretnie z jego pracy Tool-Being: Elements in a Theory of Objects. Graham użył tam terminu object-oriented philosophy, który Levi Bryant zmienił później właśnie na object-oriented ontology.

9 Sprawa jest o tyle ciekawa, że Latour, bohater być może najlepszej książki Harmana Księcia sieci, myśliciel przez Harmana podziwiany, do Heideggera odnosi się co najmniej z ironią: „Skoro »tutaj także obecni są bogowie«, to można ich znaleźć i w elektrowni wodnej na Renie, i w cząstkach elementarnych, w butach Adidasa i w struganych ręcznie starych drewnianych chodakach, w przemyśle rolnym i nietkniętych pejzażach, w kalkulacjach sprzedawcy i w rozrywającej serce frazie Hölderlina" - B. Latour, Nigdy nie byliśmy nowocześni. Studium z antropologii symetrycznej, przeł. M. Gdula, Warszawa 2011, s. 96. Natomiast Harman postrzega Heideggera jako najważniejszego filozofa XX wieku; zob. idem, Książę sieci. Bruno Latour i metafizyka, przeł. G. Czemiel, M. Rychter, Warszawa 2016, s. 113. Sama OO rzeczywiście nosi heideggerowskie znamię. Jak pisze Małecki: „U jej fundamentu leży [...] rozróżnienie na przedmioty rzeczywiste i zmysłowe, do którego dokłada się podział na jakości rzeczywiste i zmysłowe, co razem tworzy Harmanowską wersję (nie-)sławnej »czwórni« zaproponowanej przez Heideggera”-idem, op. cit., s. 274. 
Centralne koncepcje czerpię $\mathrm{z}$ pism Latoura: teorię aktora-sieci i płaską ontologię. Istotnymi inspiracjami będą też teorie rozwijane pod patronatem Deleuze'a i Guattariego — do których często odwołują się przywoływani autorzy. Jest to o tyle kłopotliwe, że te dwa główne patronaty filozoficzne — Latour z jednej oraz Deleuze i Guattari z drugiej strony — w wielu, także kluczowych, miejscach są wobec siebie konkurencyjne i proponują zupełnie odmienne podejścia. Natomiast od Bernarda Stieglera, autora monumentalnego dzieła $L a$ technique et le temps (1994, wyd. ang. 1998), zapożyczę pojęcie epifilogenezy, będące szczególnie przydatne przy interpretacji świata przedstawionego w Starości aksolotla.

Będę się ponadto odnosił do powieści Stanisława Lema Niezwyciężony, w której pojawia się pojęcie nekrosfery, mogące — jak sądzę - przysłużyć się ekokrytycznej lekturze opowiadania Dukaja, a także ekokrytyce i ekologii jako takiej. Na ekologiczne implikacje powieści Lema zwrócił uwagę już Wojciech Małecki, wskazując właśnie na nekrosferę, która ze względu na swój niebiologiczny charakter radykalnie problematyzuje pojmowanie środowiska i życia, a ponadto stwarza ważkie pole do refleksji nad ekopolityką ${ }^{10}$. Także nekrosferę chciałbym więc potraktować jako pojęcie teoretyczne, służące interpretacji zarówno opowiadania Dukaja, jak i myśli ekokrytycznej sensu largo. Jest to o tyle istotne, że w powieści Lema, podobnie jak w pismach Timothy'ego Mortona, sproblematyzowane zostają założenia ontologiczne podstawowe dla ekologicznie zorientowanej krytyki.

Konstrukcja świata przedstawionego Starości aksolotla prowokuje do podjęcia kilku filozoficznych kwestii kluczowych dla ekokrytyki czwartej fali, opartej przede wszystkim na ,nowych materializmach”. Niektóre z nich, jak na przykład zagadnienie współewolucji człowieka i techniki, splotu natury i kultury/techniki, są bezpośrednio problematyzowane w tekście. Chciałbym skupić się na następujących zagadnieniach: po pierwsze, przepracowanie kategorii życia, jakiegoś życia, aby posłużyć się Deleuzjańskim terminem ${ }^{11}$, w sposób odmienny od tego, który w swoich esejach prezentowali Joanna Bednarek ${ }^{12}$ czy Krzysztof Pacewicz $^{13}$. Być może takie radykalne ujęcie niebezpiecznie zbliża się do mętnych transhumanistycznych marzeń, czego świadomość w tym momencie zaznaczam. Kontrując te implikacje, chciałbym przenieść punkt ciężkości z informacji na wzajemnie konstytuujące się interakcje między aktorami ${ }^{14}$. Po drugie, wplotę w ekokrytykę

10 Zob. przygotowaną przez Wojciecha Małeckiego listę (bez tytułu) książek polskich autorów do prowadzonej przez Scotta Slovica, A Booklist of International Environmental Literature na łamach „World Literature Today” - W. Małecki, „World Literature Today” 2014, nr 3, https:// www.worldliteraturetoday.org/2014/may-august/booklist-international-environmental-literature-part-2 (dostęp: 22.08.2016).

11 Zob. G. Deleuze, Immanencja: życie, przeł. K.M. Jaksander, Kraków 2017.

12 Zob. J. Bednarek, Życie, które mówi. Nowoczesna wspólnota i zwierzęta, Warszawa 2017.

13 Zob. K. Pacewicz, Fluks. Wspólnota plynów ustrojowych, Warszawa 2017.

14 Oczywiście dostrzegam możliwość wyboru innej drogi do osiągnięcia tego celu, być może bliższej Dukajowym intuicjom, wiodącej przez teorie systemów Humberta Maturany, Francisca Vareli 
koncepcje pokrewne teorii aktora-sieci, w tym bardziej dynamiczne pojęcie asamblaży Deleuze'a i Guattariego, co — jak sądzę — może pomóc w ekokrytycznym odczytaniu Starości aksalotla. Stawką jest w tym wypadku przemyślenie kategorii wspólnoty, wspólnoty obiektów - jak w obiektowej ontologii — w perspektywie planetarnej, a więc chodzi o refleksję w obrębie polityczności ekologicznej.

Pozwolę sobie teraz nieco przybliżyć samo opowiadanie Dukaja: (1) w wyniku pewnej katastrofy zostaje unicestwione całe organiczne życie na Ziemi wydarzenie to będę dalej nazywał ekocydem ${ }^{15}$; (2) niewielkiej garstce, głównie zapalonych graczy komputerowych, udaje się przed śmiercią za pomocą niedoskonałego programu zapisać swoją świadomość w postaci informacji na elektronicznych nośnikach danych, dzięki czemu ocaleńcy, jako transformery (właśnie taka nazwa pojawia się w utworze Dukaja), czyli cyfrowe kopie ludzkiej świadomości zapisane na dyskach twardych robotów, zyskali możliwość uczestnictwa w obiektowym „życiu” po życiu biologicznym; (3) postludzie, którzy ocaleli z ekocydu, po latach starań odtwarzają życie biologiczne, niebędące już jednak tą samą emanacją życia co przed ekocydem — odtworzeni ludzie nazywani są ludziakami, co wskazuje na ich nie-tożsamość z gatunkiem Homo sapiens sapiens. Takie zdarzenia stały się udziałem Grzesia ${ }^{16}$ — bohatera opowiadania, specjalisty od hardware'u, któremu udało się ,przeżyć”.

Ginie więc całe życie biologiczne na Ziemi, a zatem znikają ci wszyscy aktorzy (terminu tego będę używał wymiennie z pojęciem ,aktanci”) najbardziej interesujący ekologów i ekokrytyków w sieci zwanej środowiskiem. $Z$ tego powodu niemożliwe jest skupienie się w trakcie analizy utworu na biosferze. Ten brak ujawnia inne ścieżki warte eksploracji — zagadnienia związane z nekrosferą. Pojęcie to, zaczerpnięte od Lema, chciałbym nieco rozszerzyć i objąć nim całą niebiologiczną sferę materialną. Nie powinna więc ona być tutaj pojmowana jedynie w kategoriach przedmiotów technicznych, jak w Niezwyciężonym, ale obejmować wszystkich nieożywionych aktorów wchodzących w relację z innymi aktorami, tworzących sieci relacji — ekosystemy.

czy Cary'ego Wolfe'a, które podsuwają sposoby „stworzenia teoretycznego modelu polityki i etyki, w którym człowiek nie jest głównym punktem odniesienia” (J. Żylińska, Bioetyka w epoce nowych mediów, przeł. P. Poniatowska, Warszawa 2013, s. 71), jednak wybieram inne, choć do pewnego stopnia pokrewne tradycje teoretyczne i nie ukrywam, że nie chodzi mi o wydobywanie intencji autorskich z dzieła literackiego.

15 Pojęcie ekocydu, jak pisze Aleksanda Ubertowska, ,zostało wprowadzone przez biochemika Artura Gelstona na określenie amerykańskiej operacji militarnej Ranch Hand, polegającej na rozpyleniu nad terytorium Wietnamu Południowego środków chemicznych (herbicydów), co doprowadziło do nieodwracalnego wypalenia hektarów dżungli, stanowiącej naturalną ochronę dla żołnierzy armii Wietkongu” - eadem, Natura u kresu (ekocyd). Podmiotowość po katastrofie, „Teksty Drugie" 2013, nr 1-2, s. 36.

16 Warto zwrócić uwagę na istotność użycia zdrobniałej wersji imienia, zwłaszcza w zestawieniu z samym tytułem utworu — wszak termin ,aksolotl” oznacza wodne stadium larwalne płazów z rodzaju Ambystoma. 
Interpretację samego utworu Dukaja zacznę od kwestii, która w Starości aksolotla jest bezpośrednio problematyzowana — od powiązania człowieka, jego ewolucji, z techniką - którą postaram się połączyć z myśleniem ekokrytycznym. Aby rozważyć tę kwestię, proponuję skupić się nie na wątkach transhumanistycznych, jakie można znaleźć w zaprezentowanej w opowiadaniu koncepcji transformerów, przepisującej w przewrotny sposób marzenia o przezwyciężeniu przez ludzkość stanu ucieleśnienia, ale na irigochi — robotach-zabawkach, których zadaniem przed katastrofą było towarzyszenie ludzkim dzieciom. Irigochi miały dostosowywać się do swoich właścicieli, odbijać ich cechy charakteru, nastroje i zachowanie. Po ekocydzie, pozbawione swoich dziecięcych podopiecznych, irigochi zaczęły łączyć się w większe grupy i spontanicznie tworzyć sieci, przygodne i nietrwałe układy, które Grześ nazywał wektorami, zależne od innych aktorów, z którymi wchodzą w interakcje. Swoim zachowaniem przypominają w pewnym sensie mikromaszyny tworzące nekrosferę z Niezwyciężonego.

Interesująca mnie tutaj kwestia, na którą patrzę przez pryzmat rozważań Stieglera na temat techniki, uwyraźnia się, kiedy transformerom, kierowanym melancholijnym poczuciem straty i pragnieniem powrotu do tego, co było ${ }^{17}$, udaje się odtworzyć gatunek ludzki. Jednak, o czym przekonywał Derrida, a wcześniej Kierkegaard, powtórzenie bez różnicy, a więc powrót do tego, co było, jest niemożliwe. Dlatego też ostatecznie powstają nie ludzie, ale „ludziaki”, istoty genetycznie identyczne ze swoim pierwowzorem, a jednak diametralnie inne. Różnica ta jest oczywiście wynikiem odmiennego środowiska, innych sieci relacji, w jakie wchodzą ludziaki, a zatem wiąże się ze zjawiskiem epigenezy ${ }^{18}$ — ,problem epigenezy spędzał Grzesiowi sen z powiek. (Nie z powiek, i nie do końca sen — ale

17 „Grześ doskonale rozumiał tęsknoty transformerów za życiem utraconym; była to przecież główna emocja jednocząca, patriotyzm ich transformerowy. Jeśli za ojczyznę uznać nie miejsce, lecz czas: lata sprzed Zagłady" — J. Dukaj, Starość aksolotla, s. 87/584.

18 Starość aksolotla opatrzona została skorowidzem pojęć pojawiających się na kartach opowiadania. Przeczytać w nim możemy między innymi, że: „epigeneza — proces rozwoju organizmu poprzez różnicowanie komórek, od zarodka; organizm nie rośnie od miniaturowej swojej wersji [taki pogląd, zwany preformizmem, popularny w XVII wieku, zakładał, że w plemniku lub w komórce jajowej znajduje się miniaturowy organizm ludzki, homunculus - J.W.], lecz wytwarza w jednostkowym rozwoju kolejne części i organy. Epigenetyka (epigeneza + genetyka) to nauka o dziedziczeniu poza informacją genetyczną. Epigenetyczna jest np. sama informacja o uruchamianiu lub wyciszaniu ekspresji genów. Mechanizmy epigenetyczne stanowią jedną z największych tajemnic biologii" - ibidem, s. 361/584. Epigenom natomiast został zdefiniowany w sposób następujący: ,»drugi kod « w komórkach ludzkiego ciała: pakiet zmian chemicznych DNA i histonów, podlegających dziedziczeniu. Zmiany epigenomu powodują uruchamianie bądź wyciszanie "pierwszego kodu« (genetycznego). Wpływ na epigenom mają warunki zewnętrzne, styl życia, dieta itp." — ibidem, s. 362/584. Szczególnie ostatnie zdanie zawarte w drugiej definicji zdaje mi się istotne w kontekście niniejszych rozważań. 
uczucie to samo)"19 — która staje się jednym z głównych tematów opowiadania, a refleksje bohatera związane $\mathrm{z}$ tym zagadnieniem pojawiają się niemal zawsze, kiedy przypatruje się on nowemu Życiu. To, co „spędza Grzesiowi sen z powiek”, to tak naprawdę środowisko egzystencji nowych ludzi, sieci, które tworzą i będą tworzyć z innymi aktorami - organicznymi i nie-, sferą kultury i odtworzoną (niedoskonale) naturą — oraz pytanie, jak wpłynie to na rozwój całego gatunku. Szczególnie uderzające zdają się trzy fragmenty opowiadania.

Pierwszy zawiera scenę, w której Grześ obserwuje Fredka — jednego z nowych ludzi, wyhodowanych i wychowanych pod czujnymi kamerami transformerów i „robotów AGD”. Widok Fredka, zawsze otoczonego irigochi, wychowywanego na szczątkach kultury ludzi sprzed ekocydu, w sztucznie stworzonym ekosystemie, prowokuje Grzesia do refleksji nad przyszłością ewolucyjną odtworzonej ludzkości, nad niegenetycznymi determinantami ewolucji.

Drugi istotny w tym kontekście fragment dotyczy bezpośrednio problemu epigenezy, która zdaniem bohatera utworu „wymyka się analizie technicznej”20. Warto tutaj przytoczyć rozmowę między bohaterem a transformerem będącym specjalistą od genetyki:

- Bierzesz dokładnie takie samo DNA - opowiadał Jarlinka — implantujesz i rozwijasz w dokładnie takich samych warunkach, a jednak na końcu dostajesz różne organizmy.

- Więc to mimo wszystko nie są ludzie? Znaczy, nie jak sprzed Zagłady?

— Cóż, genom jest ten sam. Ale sposób ekspresji genów — które geny się włączają, które nie, i na jakim etapie - to wszystko jest zapisane poza DNA, w ciągłości pamięci międzypokoleniowej. [...] Czytałeś, że metylacja odbija ci na DNA cały tryb życia, traumy, choroby, status materialny, wykształcenie, miejsce zamieszkania, powietrze, jakim oddychasz? Albo weź dziedziczne ekspresje środowiskowe. Albo...

- Czyli geny mają swoją kulturę.

- Hę?

- Wyjmiesz człowieka z kultury i wychowasz w dziczy, i też dostaniesz zwierzę, nie człowieka. Kultura nie jest kodowana w DNA.

$[\ldots]$

- Chodzi o to - próbował się Grześ wytłumaczyć Jarlince, a display rzygał mu sieczką stroboskopowych skojarzeń - że już za parę lat oni zaczną się sami rozmnażać i wychowywać własne dzieci, oni, pierwszy-drugi miot, i to się nieuchronnie przekopiuje na wszystkie pokolenia w przód. Jak w pierwszej sekundzie po Big Bangu mikroskopijna nierówność kwantowa ustawia kształt galaktyki i gromad galaktyk, tak teraz te kilka lat ich dzieciństwa - zabawy, kołysanki, piastunki, bajki, kary i nagrody — ustawi kształt całej nowej ludzkości ${ }^{21}$.

W przytoczonej partii tekstu chciałbym zwrócić uwagę przede wszystkim na fakt ukazania sieciowych relacji między aktorem ożywionym (na przykład Alicją, ulubioną podopieczną Grzesia) a aktorami nieożywionymi, przedmiotami (irigo-

\footnotetext{
19 Ibidem, s. 70/584.

20 Ibidem.

21 Ibidem, s. 70-72/584.
} 
chi, Matternetem, czyli — dosłownie — siecią materii), i zinterpretować je w duchu stieglerowskim ${ }^{22}$.

Dekonstrukcja „dualizm[u] człowiek-narzędzie”23, której dokonuje Stiegler, nie tyle ma na celu odwrócenie relacji, ile wskazanie sztuczności i upłynnienie jej. Podobne refleksje prowokuje przedstawienie transformerów - istot nierozerwalnie związanych z techniką, stanowiącą podstawę ich istnienia - w Starości aksolotla. Wszak sytuacja egzystencjalna, w jakiej znalazł się Grześ, jest doskonałym przykładem zniesienia podziału na episteme i techne, na podmiot i przedmiot w relacji człowiek-technika. Człowiek (czy też postczłowiek) w utworze Dukaja jawi się jako istota nierozerwalnie złączona z protetyczną rzeczywistością tworzoną przez obiekty techniczne, w które wpisana jest potencjalność ewolucyjna i które współkonstytuują z ludzkością jeden ekosystem. Tak jak w myśli Stieglera człowiek przedstawiany jest tu jako asamblażowa istota techniczna ${ }^{24}$.

W przytaczanej rozmowie Grzesia z Jarlinką nietrudno zauważyć, że obserwacja ludziaków oraz doświadczenia wyniesione z pracy przy odtwarzaniu życia biologicznego i gatunku Homo sapiens sapiens prowadzą do konstatacji wykraczających poza dziedzinę genetyki w kierunku antropologii. Głosem Grzesia wypowiadany jest tutaj bardzo stieglerowski pogląd, że ,antropogeneza nie daje się sprowadzić do ewolucji genetycznej”"25. W tym miejscu Starości aksolotla bezpośrednio zostaje poruszone zagadnienie epigenezy. Sądzę jednak, że do zrozumie-

${ }^{22} \mathrm{~W}$ Technics and Time Stiegler rozwija szczegółowe analizy znaczenia techniki, wychodząc z założenia, że była ona „represjonowana” w dotychczasowej myśli filozoficznej. Zdaniem autora stanowi formę zorganizowanej nieorganicznej materii i jako forma pamięci (w jego ujęciu kultura jest systemem transmisji pamięci - B. Stiegler, Technics and Time 3: Cinematic Time and the Question of Malaise, przeł. S. Barker, Stanford 2011, s. 131) jest konstytutywna dla ludzkiej czasowości, tworzy horyzont ludzkiej egzystencji. Stiegler stawia sobie za cel udowodnienie, że filozofia nigdy nie zaprzestała powielać rozróżnienia na episteme i techne, oraz przezwyciężenie tego błędu. Pierwszy tom, noszący podtytuł The Fault of Epimetheus (idem, Technics and Time 1: The Fault of Epimetheus, przeł. R. Beardsworth, G. Collins, Stanford 1998), opierający się w dużej mierze na odczytaniach antropologii André Leroi-Gourhana, historii techniki Bertranda Gille'a i filozofii Gilberta Simondona, problematyzuje prosty podział na „kto?” i „co?”, na podmiot i przedmiot w relacji człowiek-technika.

${ }^{23}$ K. Słotwińska, Bernard Stiegler: wynalazek człowieka, czyli filozofia wobec współczesności, [w:] Po humanizmie. Od technokrytyki do animal studies, red. Z. Ładyga, J. Włodarczyk, Gdańsk 2015, s. 262.

24 Jak pisze Karolina Słotwińska, Stiegler twierdzi, że „osobliwość relacji tworzonej przez tendencję techniczną zasadza się na tym, że w toku procesu konstruowania, tj. organizowania obiektu technicznego, obiekt ten ewoluuje i zaczyna kształtować swoje otoczenie. Podobnie jak w przypadku systemu technicznego należy więc mówić o wpisanej w obiekt techniczny możliwości ewolucyjnej (potencjalności), która oddziałuje na istoty żyjące. W konsekwencji, stwierdza Stiegler, człowiek okazuje się istotą techniczną zatopioną w rzeczywistości na wskroś protetycznej - konstytuowanej przez obiekty techniczne i wraz z człowiekiem tworzącej swoisty ekosystem" ibidem, s. 264. Analizy dokonane przez Stieglera prowokują do włączenia w ramy ekosystemu nie tylko Renu, lecz także elektrowni wodnej na zasadzie przywodzącej na myśl teorię sieci Latoura czy koncepcje asamblaży Deleuze'a i Guattariego rozwijane dalej przez Manuela DeLandę.

25 Ibidem, s. 267. 
nia sytuacji przedstawionej w utworze lepiej nadaje się stieglerowski termin „epifilogenezy", który oznacza proces ,akumulacji i sedymentacji następujących po sobie epigenez, gdzie epigeneza jest procesem formowania się pamięci indywidualnego organizmu" ${ }^{26}$. Definicja epigenezy różni się tutaj od tej zamieszczonej w Starości aksolotla, jednak nie brakuje między nimi punktów wspólnych. Dla mnie istotne będzie to, że obie podkreślają istotność informacji pozagenetycznej, a co za tym idzie wskazują, że „wpływ na epigenom mają warunki zewnętrzne, styl życia, dieta itp."27. Owe warunki zewnętrzne to dla Stieglera (lecz także dla Grzesia) przede wszystkim technika, która pozwala zachować pamięć organizmu dłużej, niż trwa jego biologiczne życie ${ }^{28}$.

Chciałbym teraz przywołać wspomniany trzeci fragment ze Starości aksolotla, którego siła performatywna okazała się odpowiednio duża, by ukształtować całą moją interpretację opowiadania Dukaja. W omawianym utworze pojawia się jeszcze jedna przedstawicielka genetycznie odtworzonej ludzkości — Alicja, z którą Grześ nawiązał wyjątkowo bliskie relacje. Dziewczynka zawsze go rozpoznaje, niezależnie od tego, w jakim mechanicznym ciele się on pojawia. Istotna jest scena, w której Alicja, otoczona chmarą irigochi, bawi się wśród opadłych z drzew kolorowych liści, a w tym samym czasie Grześ po raz kolejny odbywa antropologiczną rozmowę z innym transformerem. W jej trakcie wyraża ważne spostrzeżenia na temat związku ludziaków i techniki: „To nie jest tak, że wektory odbijają się w irigochi i w Matternecie, zdjęte z zachowania naszych dzieciaków. Jest raczej tak, że dzieci są tymi wektorami, częścią wektorów — dokładnie tak samo jak irigochi" ${ }^{29}$. Na pytanie swojego rozmówcy, czy ludzkie dzieci mają wszczepione neuroczipy, Grześ odpowiada: „Nie, one po prostu się w tym wychowały, wrosły w to od niemowlęctwa. Więc za kim będę tęsknił - za Alicją czy za tym fenotypem wektorów? Gdzie się kończy Chwała Jesieni, a zaczyna Alicja?"30.

W wypowiedzi Grzesia można dostrzec dekonstrukcję dualizmu podmiot-przedmiot podobną do tej przeprowadzonej przez Stieglera. Koncepcja epifilo-

26 B. Stiegler, Technics and Time 1..., s. 114, cyt. za: K. Słotwińska, op. cit., s. 268.

27 J. Dukaj, op. cit., s. 362/584.

28 Jak komentuje Słotwińska, ,o ile w ramach ewolucji genetycznej pamięć organizmu zostaje utracona w momencie jego śmierci, niezależnie od czynników epigenetycznych, które są osobnicze, o tyle epifilogeneza — rodzaj ewolucji łączący w sobie logikę genetyczną i techniczną — umożliwia zachowanie tej pamięci dłużej niż życie jednego osobnika gatunku, dzięki zapisaniu jej w narzędziu" - eadem, op. cit., s. 268. Warto też dodać, że w ujęciu Stieglera relacja między człowiekiem a przedmiotem technicznym (techniką) jest relacją transduktywną, co oznacza, że oba elementy konstytuują się wzajemnie i nie można jednoznacznie przypisać im pozycji podmiotu i przedmiotu (zob. ibidem, s. 269). Być może ujawnia się tutaj pewne pokrewieństwo z myślą Deleuze'a i jego koncepcją kłącza — transduktywność została zaczerpnięta od Simondona, którego myśl inspirowała także autora Tysiąc plateau — jednak wolałbym rozważania Stieglera o epifilogenezie połączyć $\mathrm{z}$ teoriami Brunona Latoura.

29 J. Dukaj, op. cit., s. 76/584.

30 Ibidem. 
genezy umieszcza esencję bytu — tu: człowieka — nie w jego wnętrzu, nawet nie „,na nim”, jak postmodernistyczne koncepcje podmiotowości, lecz w sieci relacji, w jakie wchodzi, na przykład z przedmiotem technicznym, a zatem pomiędzy bytami. Stiegler łączy antropogenezę z relacją człowiek-przedmiot techniczny. W opowiadaniu Dukaja mamy do czynienia właśnie z taką sytuacją. Dla Alicji i innych ludziaków otaczające je przedmioty, urządzenia stanowią jednak coś więcej — środowisko, ekosystem, którego są częścią, które determinują i przez które są determinowane. Dlatego też można mówić tutaj o sieci.

Analizy Stieglera oraz latourowska płaska ontologia i teoria aktora-sieci ujawniają ścisły związek między bio- i nekrosferą, ich wzajemne oddziaływanie i ewolucję. Takie podejście wydaje mi się niezbędne, aby ująć Starość aksolotla i świat po ekocydzie w ramy krytyki ekologicznej, zwłaszcza w jej nowomaterialistycznej wersji, problematyzującej pojęcie życia.

$$
* * *
$$

W opowiadaniu Dukaja życie transformerów jest sprowadzone do informacji — do odcieleśnionej świadomości. Jest życiem o tyle, o ile mówi ${ }^{31}$, o ile wytwarza komunikaty, informacje. Biologiczność życia zostaje przekroczona więc w iście transhumanistycznym duchu, nawet jeśli owo przekroczenie ludzkiej kondycji ucieleśnienia następuje w drodze przymusu. W tym ujęciu wspólnota bytów, zorganizowana wokół logocentryzmu, na powrót staje się hierarchiczna ${ }^{32}$. Dlatego też aby przezwyciężyć te transhumanistyczne implikacje, stawiające w centrum istoty posługujące się językiem, chciałbym wykorzystać wymienione wcześniej koncepcje i zamiast skupiać się na wątkach Starości aksolotla, które skłaniają do logocentrycznej hierarchizacji bytów, wskazać obecne w opowiadaniu decentralizujące zagadnienia nekrosfery i sieci, co uważam za bardziej owocną ścieżkę interpretacji z punktu widzenia posthumanistycznej ekokrytyki.

$\mathrm{Na}$ ekokrytyczne implikacje pojęcia nekrosfery ${ }^{33}$ zwracał uwagę Wojciech Małecki ${ }^{34}$, pisząc, że ten specyficzny ekosystem, ze względu na swój niebiologiczny charakter, radykalnie problematyzuje nasze pojmowanie środowiska i życia, a ponadto stwarza ważkie pole do refleksji nad ekopolityką. Zarówno powieść Lema, jak i opowiadanie Dukaja zmuszają do przemyślenia podstawowych dla ekologicznie zorientowanej krytyki założeń, wskazując na płynność życia, które

31 Zob. J. Bednarek, op. cit.

32 Jest to dość ironiczne zradykalizowanie konceptów przedstawianych przez Joannę Bednarek w eseju Życie, które mówi. Nowoczesna wspólnota i zwierzęta, wprowadzające na powrót kartezjański podmiot.

33 Ten Lemowski koncept wymaga myślenia poza tradycyjnym witalizmem i zwrócenia się w stronę nieorganicystycznego słownika Deleuze'a i/lub obiektowej ontologii. Pojęcie to można potraktować jako radykalną interwencję w dziedzinę bioetyki i biopolityki, co najmniej tak radykalną jak interpretacja etyki spinozjańskiej dokonana właśnie przez autora Logiki sensu.

34 Por. W. Małecki, „World Literature Today”... 
ująć można za Timothym Mortonem antyesencjalistycznie jako niepodlegającą totalizacji siatkę (mesh), sprowadzającą się do interrelacji. Celem takiego ujęcia jest rozmycie granic między gatunkami, między ożywionym a nieożywionym oraz między organizmem a środowiskiem ${ }^{35}$.

Ten sam ruch dostrzegam w Starości aksolotla, w której elementem najlepiej obrazującym to założenie oraz zagadnienia związane z siecią tworzoną przez różnych aktorów, są wspomniane już irigochi. Co więcej, ilustrują one to, co zdaje się niewidoczne w powieści Lema, a mianowicie założenie, że wszystkie formy bytów „razem ze środowiskiem, które tworzą i zamieszkują, rzucają wyzwanie granicom pomiędzy zewnętrznym i wewnętrznym na każdym poziomie"36, a więc także między życiem a nie-życiem, między bio- a nekrosferą, a także między indywidualnym życiem a ,jakimś życiem” (Deleuze), właśnie dlatego, że nie istnieją indywidualnie, poza siecią.

Świat po ekocydzie przedstawiony w opowiadaniu staje się niehierarchicznym światem obiektów, dlatego też chciałbym spojrzeć na katastrofę ukazaną w opowiadaniu Dukaja jako ,poniżenie” humanistycznego, nowoczesnego podmiotu i spłaszczenie hierarchii bytów (być może było to właśnie zamiarem aktora, który wymazał życie biologiczne). Martwe drzewa, góry, tokijskie wieżowce mają taki sam status - bytu materialnego. Również świadomość Grzesia, roboty, z których korzysta, czy programy imitujące sen są aktantami performującymi na tej samej płaszczyźnie, tworzącymi sieci i będącymi nimi. Ekocyd byłby w takim metaforycznym ujęciu kontrrewolucją wobec filozofii, która postawiła ludzi w centrum, „redukując przy tym resztę świata do zbioru niepoznawalnych przedmiotów" ${ }^{37}$. Po zburzeniu starego porządku ontologicznego konieczne jest budowanie nowej, płaskiej ontologii, która stanowi radykalną granicę myślenia o relacjach bytów, co zdaje się jednym z podstawowych zadań ekologii i ekokrytyki. W takiej perspektywie Starość aksolotla można odczytać ekokrytycznie i dostrzec, że opowiadanie Dukaja może dawać impuls do wyobrażenia sobie nowomaterialistycznego porządku, w którym „człowiek” zostaje, używając wyrażenia Timothy'ego Mortona, poniżony ${ }^{38}$.

35 T. Morton, Queer ecology, „Publications of the Modern Language Association” 2010, nr 2, s. 275-276; jeśli nie podano inaczej, przeł. J.W.

36 Ibidem, s. 274.

37 G. Harman, Książe sieci..., s. 99.

38 Dla Timothy'ego Mortona jednym z głównych prądów myślowych „poniżających człowieka" - jak heliocentryzm, teoria ewolucji, marksizm czy psychoanaliza — jest ekologia, ponieważ wskazuje, iż nie stoi on w centrum/najwyżej w hierarchii bytów (idem, op. cit., s. 277). „Poniżanie" można rozumieć tutaj dosłownie, ale nie pejoratywnie. Ekologia w ujęciu Mortona nie toleruje ontologicznych nierówności, w czym przypomina metafizykę Latoura, który w swych wczesnych pismach usiłował przełamywać hierarchię bytów (zob. np. B. Latour, Nadzieja Pandory. Eseje o rzeczywistości w studiach nad nauka, przeł. K. Abriszewski et al., Toruń 2013; idem, Splatając na nowo to, co społeczne. Wprowadzenie do teorii aktora-sieci, przeł. A. Derra, K. Abriszewski, Kraków 2010) i tym samym zbliżał się do poglądów charakterystycznych dla płaskiej ontologii (zob. 
W tak wyobrażonej rzeczywistości aktanci są realni tylko poprzez swoje oddziaływanie na inne elementy sieci i — co więcej — nie są określani przez jakąś wewnętrzną esencję czy własne cechy, ale przez to, co ,zmieniają, przekształcają, zakłócają lub wytwarzają"39. Specyficzny ekosystem w Starości aksolotla, złożony z irigochi, transformerów wraz z ich oprogramowaniem i ludziaków, nosi znamiona latourowskiej metafizyki specyficznie przetworzonej przez Harmana ${ }^{40}$ i dlatego sądzę, że świat przedstawiony utworu z powodzeniem można interpretować właśnie z takiej perspektywy.

Latourowska płaska ontologia i teoria aktora-sieci ujawniają niewystępowanie hierarchicznego porządku ontologicznego i ścisły związek między bio- i nekrosferą, ich wzajemne oddziaływanie oraz ewolucję jako aktorów społecznych. Również lektura Starości aksolotla pokazuje byty istniejące jedynie poprzez swoją relacyjność ${ }^{41}$. Ilustracją takiej właśnie ontologii zdają się w opowiadaniu Dukaja irigochi i wektory, które tworzą, którymi są. Każdy układ jest nowym wektorem, następującym w czasie po poprzednim, a więc ma zdolność do terytorializacji, deterytorializacji i reterytorializacji. Właśnie to zauważył Grześ, obserwując zachowanie swoich ludzkich podopiecznych oraz — w szerszej perspektywie ewolucję odtworzonych gatunków. Używając sformułowań bliskich Latourowi, można by powiedzieć, że Grześ, rozważając znaczenie epigenezy, dochodzi do wniosku, że aktanci nie różnią się od relacji, w jakich pozostają, są sumą swoich relacji. Obserwacje takie rezonują z płaską ontologia, opartą nie na esencji, ale na społecznym performowaniu aktorów, co pozwala przemyśleć kwestie wspólnoty bytów w perspektywie materialistycznej ekokrytyki i rozszerzyć kategorię sprawczości przez uwidocznienie, że nie może być ona sprowadzona do sprawczości jednostkowej, ponieważ zawsze dotyczy splątanej sieci bytów ludzkich

M. DeLanda, Intensive Science \& Virtual Philosophy, London-New York 2002; G. Harman, Książe sieci..., s. 6). Zgodnie z taką spłaszczoną, niehierarchiczną metafizyką świat składa się wyłącznie z aktorów lub aktantów, wchodzących z sobą w relacje, tworzących sieci, zwiększających lub zmniejszających swoje moce.

39 G. Harman, Ksiaże sieci..., s. 7.

40 Metafizykę Latoura Harman wykłada w następujący sposób: „wszystkie aktanty — wielkie i małe, ludzkie i nieludzkie - mają taką samą podstawę. Żaden nie jest jedynie pożywką dla innych; każdy w sobie tylko właściwy sposób wzmacnia inne lub stawia im opór. Skoro każdy aktant jest absolutnie konkretny, jego realności nie należy się doszukiwać w pewnej samotnej istocie, czy też czystym substracie, lecz zawsze w określonym miejscu świata i w określonych sojuszach, jakie zawiera w danej chwili. Wszystko w świecie jest immanentne, nic nie przekracza konkretności. [...] Świat wedle Latoura jest polem wypełnionym przez przedmioty, czy też aktanty uwikłane w próby sił niektóre stają się silniejsze dzięki rosnącej liczbie asocjacji, inne stają się słabsze i bardziej samotne, gdy maleje liczba ich powiązań" - G. Harman, Książe sieci..., s. 27. W takim samym duchu kreuje swój projekt Timothy Morton - idem, op. cit., s. 277.

41 T. Morton, op. cit., s. 277. 
i nie-ludzkich. Obraz tego splątania, niezależnie od tego, czy zostanie nazwane ono siecią, asamblażem czy wektorem, chciałbym wydobyć ze Starości aksolotla.

W tym celu należy przywołać pewną scenę z opowiadania Dukaja - po latach starań transformerom udało się odtworzyć życie biologiczne, także ludzi, którzy wychowują się w ośrodkach badawczych pod okiem transformerów, wchodząc $\mathrm{w}$ interakcje $\mathrm{z}$ masami irigochi. Jednym z przedstawicieli nowo odtworzonego gatunku ludzkiego jest Alicja, ulubienica Grzesia. Interpretacyjnie istotny jest dla mnie moment, w którym Grześ obserwuje interakcje między Alicją i irigochi. Zauważa on, że irigochi właściwie nie zachowują substancjalnej ciągłości ${ }^{42}$. Każdy układ jest nowym wektorem, następującym w czasie po poprzednim i równie nietrwałym — to jeden z powodów, dla których postrzegam te przedmioty jako doskonałą ilustrację pojęcia aktora/aktanta ${ }^{43}$. Grześ dostrzega także, że nie można przeprowadzić dokładnej dystynkcji między Alicją a wektorami irigochi. Nie wyciąga on jednak ze swojej obserwacji ostatecznych wniosków — nie tylko Alicja i inne dzieci tworzą i są tworzone przez wektory; również sam Grześ i wszyscy inni aktorzy tworzący sieci nie mogą być dłużej ujmowani w kategoriach odizolowanych indywidualności. Zauważa więc, że zaciera się ontologiczna dystynkcja podmiot-przedmiot (obiekt), a samo życie staje się monstrualne, niejednostkowe, niepozwalające zamknąć się w opozycji wnętrze-zewnętrze czy organiczne-nieorganiczne, martwe-żywe.

Pojęcie wektorów, którym posługuje się Grześ, podobnie jak teoria aktora-sieci czy koncepcja asamblaży Deleuze'a i Guattariego, podkreśla płynność i zmienność relacji poszczególnych elementów systemu, które mogą przemieszczać się i wymieniać z elementami innego systemu, a także prowadzi do przekroczenia granicy natura-kultura ${ }^{44}$. Umieszcza także aktorów ożywionych i nie-

42 Zagadnienie ,substancjalnej ciągłości” zapożyczam tutaj z pism Latoura oraz Harmana; zob. B. Latour, The Pasteuruzation of France, przeł. A. Sheridan, J. Law, Cambridge, MA 1988; G. Harman, Książę sieci..., s. 30.

43 Jak stwierdza Harman: „Aktanty ponadto, w przeciwieństwie do substancji, nie różnią się od relacji, w jakich pozostają" (ibidem, s. 30), natomiast w ujęciu Latoura aktor jest wyłącznie sumą relacji, w które jest włączony w konkretnym miejscu i czasie. Należy zaznaczyć, że w obrębie ruchu zwanego realizmem spekulatywnym, do którego Harman należy, sympatie i antypatie filozoficzne są bardzo nieprzejrzyste. W końcu, jak zauważa Szymon Wróbel, „nade wszystko odnajdujemy w tej szkole wolę i potrzebę powrotu do wielkich filozofów substancji - Arystotelesa, Spinozy i Leibniza" - idem, Przedmowa do polskiego wydania. Otchłań przedmiotu. O filozofii, która nie jest już strażniczka bytu, [w:] G. Harman, Traktat o przedmiotach, przeł. M. Rychter, Warszawa 2013, s. XVIII.

44 Jak pisze Harman, „nie ma dwóch odgrodzonych od siebie sfer zwanych »światem« i »człowiekiem«, które należy połączyć jakimś magicznym mostem. Są jedynie aktanty i w większości przypadków nie można precyzyjnie określić, do której ze sfer (»natury« czy »kultury«?) dany aktant przynależy" — idem, Książe sieci..., s. 96. W tym kontekście można by przywołać zyskujące na popularności pojęcie naturo-kultury, rozbijające klasyczny dualistyczny podział (zob. np. B. Latour, Nigdy nie byliśmy nowocześni ...) lub naturokultury (zob. D. Harraway, When Species Meet, Minneapolis 2008; eadem, The Companion Species Manifesto: Dogs, People, and Significant Otherness, Chicago 2003 - na język polski został przetłumaczony fragment tej publikacji: eadem, 
ożywionych, należących do bio- i nekrosfery, ludzkich i nie-ludzkich na jednym poziomie i pozwala dostrzec społeczną sprawczość nie-ludzkich aktorów, w tym tych należących do nekrosfery.

$\mathrm{Na}$ istotną kwestię, będącą nicią łączącą w moim ujęciu opowiadanie Dukaja z przywoływanymi konceptami, zwraca uwagę sam Grześ, co czytam też jako komentarz do rzeczywistości pozaliterackiej — odtworzeni przedstawiciele Homo sapiens sapiens, nazywani pieszczotliwie (?) ludziakami, funkcjonują w środowisku, którego układ (układ rzeczy nieożywionych) ma olbrzymie znaczenie dla ich przyszłego rozwoju, nie tylko jednostkowego, lecz także gatunkowego. Nekrosfera wraz z biosferą, czyli szeroko pojęte środowisko, ekosystem — wedle intuicji Manuela DeLandy czy Jane Bennett — stają się aktorami społecznymi, tworzącymi historię nowej ludzkości. Dlatego też być może zamiast o gatunkach stowarzyszonych czy cyborgach powinniśmy raczej, w obrębie ekokrytyki, mówić po prostu o aktorach społecznych, sieciach lub asamblażach ${ }^{45}$, co pozwoliłoby wytworzyć odpowiedni język do mówienia o specyficznych intymnościach w relacjach między bio- i nekrosferą, które razem łączą się w większe obiekty, w pewien kolektyw, nazywany przez Grzesia wektorem, a także na rozszerzenie pojęcia społecznej sprawczości nie tylko na organizmy nie-ludzkie, ale też — w myśl płaskiej ontologii — na byty nie-żywe, a nawet kulturowe ${ }^{46}$. Takie podejście, charakterystyczne dla nowych materializmów, odwołujących się zarówno do teorii Latoura, jak i pojęcia asamblaży, zaczerpnięte z pism Deleuze'a i Guattariego, skłania do rozważenia podmiotowości rzeczy nieożywionych, związków nieorganicznych oraz ludzkiej przedmiotowości - spojrzenia na obdarzone świadomością ciało jako przedmiot wchodzący w relacje z innymi przedmiotami na równych prawach.

Starość aksolotla, choćby dzięki obserwacjom czynionym przez Grzesia na temat epigenezy, zwraca uwagę właśnie na tę problematykę — sieciowe relacje

Manifest gatunków stowarzyszonych, przeł. J. Bednarek, [w:] Teorie wywrotowe. Antologia przekladów, red. A. Gajewska, Poznań 2012).

45 Słowo assemblage wydaje mi się terminem szczególnie zgrabnie uchwytującym zależności między aktantami, również w Starości aksolotla. Na płaszczyźnie filozoficznej odsyła przede wszystkim do pism Deleuze'a i Gauttariego, wykorzystywanych i przetwarzanych później na przykład przez Jane Bennett czy Mauela DeLandę. Słowo to zdaje się również szczególnie trafne nie tylko ze względu na wskazane teorie filozoficzne - także względem opisu sposobu istnienia (nie)fikcjonalnych postaci, przedmiotów, literatury czy jej czytelników. Assemblage to po francusku ,gromadzenie”, „zbieranie”, „zbiór”. Asamblaże — jako forma sztuki — składają się z najróżniejszych przedmiotów, bezużytecznych fragmentów, przedmiotów codziennego użytku. Artysta nie wytwarza elementów, a jedynie je łączy. W ten sposób powstaje układ o nowym znaczeniu i nieoczywistych związkach. Wszystkie elementy oddziałują na siebie wzajemnie, każdy jest aktorem w sieci połączeń, ale żaden nie determinuje ostatecznie całego układu. Jak pisze Jane Bennett: „asamblaże to spontaniczne (ad hoc) zgrupowania zróżnicowanych elementów, wibrującej materii różnego rodzaju" - eadem, Vibrant Matter..., s. 23.

46 Wszak w myśl teorii zaliczanych do nowego materializmu ,asamblaże składają się z różnorodnych ciał, które wchodzą ze sobą w produktywne relacje, generując nieprzewidywalne i innowacyjne efekty" - K. Pacewicz, op. cit., s. 164. 
między przedmiotami oraz status relacji podmiot-przedmiot. Aby odczytać Starość aksolotla z perspektywy ekokrytycznej, to właśnie na tę kwestię należy położyć szczególny nacisk. Cytując Bennett, „ludzkość i nie-ludzkość zawsze znajdowały się w skomplikowanym tańcu z sobą. Nigdy ludzka sprawczość nie była czymś innym niż splątaną siecią ludzkości i nie-ludzkości" ${ }^{77}$. I właśnie obraz tego splątania, niezależnie od tego, czy zostanie nazwane siecią, czy asamblażem, czy wektorem, uwyraźnia Starość aksolotla, stając się przez to swoistą antropofikcją.

Aktor w teorii Latoura jest przede wszystkim źródłem akcji, może być ludzki lub nie, najczęściej jednak jest kombinacją, a więc sam w sobie tworzy pewien układ, jest asamblażem, aktorem-siecią czy — stosując terminologię zaczerpniętą z opowiadania Dukaja - wektorem. W kontekście rozważań i obserwacji bohatera utworu zasadne zdaje się mówienie o zastąpieniu indywidualnej podmiotowości wizją podmiotowości transindywidualnej, usieciowionej. Zakwestionować można jednak, odwołując się do myśli Briana Massumiego ${ }^{48}$, korzystającego z Deleuzjańskiej teorii afektów, nie tylko podmiotowość jako taką, lecz także indywidualność cielesną — czy to przez wskazanie na zjawisko przepływu afektów, czy też właśnie poprzez koncepcje asamblaży czy aktora-sieci. Przyjęcie takich założeń sprawia, że konieczne staje się przemyślenie etyki w kategoriach nie-ludzkich, posthumanistycznych, a więc przemyślenie bio- i ekopolityki w kontekście poszerzonej wspólnoty.

Uwagi poczynione odnośnie do usieciowionego statusu podmiotów, aktorów społecznych, takich jak transformery, irigochi czy ludzkie dzieci, nie są oczywiście autonomiczne względem podnoszonej wcześniej kwestii życia indywidualnego i jakiegoś życia. Utwór Dukaja (a także Niezwyciężony Lema) zmusza czytelnika do przemyślenia opozycji życie-martwa materia. Żeby to zrobić, warto sięgnąć do filozofii Jane Bennett, która w Vibrant Matter dąży do zbudowania podstaw myślenia poza takim dualizmem ${ }^{49}$.

Dla myślenia o świecie po ekocydzie, świecie materii nieożywionej, w kategoriach ekologicznych istotne jest przyjęcie kilku założeń wypracowanych przez Deleuze'a i Guattariego na podstawie monistycznej filozofii Spinozy, rozwijanych między innymi właśnie przez Jane Bennett czy Rossi Braidotti, które można by zaliczyć do witalistycznego materializmu. Jak pisze autorka Podmiotów nomadycznych:

na „spuściznę spinozjańską” składa się koncepcja aktywnego monizmu, która pozwoliła owym nowoczesnym filozofom francuskim [głównie Deleuze'owi i Guattariemu - J.W.] zdefiniować materię jako witalną i samoorganizującą się, a co za tym idzie wytworzyć nadzwyczajną kombinację ,witalistycznego materializmu”. Jako że podejście to odrzuca wszelkie formy transcendencji, znane jest również jako „radykalna immanencja” ${ }^{\text {" }}$.

47 J. Bennett, Vibrant Matter..., s. 31.

48 Zob. B. Massumi, Autonomia afektu, przeł. A. Lipszyc, „Teksty Drugie” 2013, nr 6.

49 Choć - jak sądzę - podstawy do tego może zapewnić przyjęcie latourowskiej płaskiej ontologii, Bennett podąża nieco inną drogą.

50 R. Braidotti, Po człowieku, przeł. J. Bednarek, A. Kowalczyk, Warszawa 2014, s. 132. Na marginesie warto zauważyć, że również ontologia Latoura określana jest jako radykalnie immanen- 
Podstawą tego stanowiska jest zaczerpnięte od Spinozy przeświadczenie o jedności wszelkiej materii, wzmocnione przez ugruntowane we współczesnej nauce pojęcie samoorganizujących się struktur żywej materii ${ }^{51}$.

W Vibrant Matter Bennett łączy Latourowską koncepcję aktora-sieci z deleuzjańsko-spinozjańsko-bergsonowską filozofią przepływu. Badaczka przekonuje, że wydarzenia społeczne są wynikiem działania aktorów rozumianych jako asamblaże, sieci ludzkich i nie-ludzkich aktantów ${ }^{52}$. Jak twierdzi Bennett, ci nie-ludzcy aktanci uczestniczą w heterogenicznych asamblażach, w których sprawczość nie jest przypisana do jednego aktanta, ale „rozdystrybuowana wśród mrowia różnorodnej wibrującej/żywej materialności"53. Materialność ta nie równa się w ujęciu Bennett organizmom żywym. Korzystając z pism DeLandy, autora Assemblage Theory, badaczka wskazuje raczej na zdolność nieorganicznej materii do samoorganizacji i na takiej podstawie pisze o vibrant matter.

Podejście Bennett jest więc różne od myślenia, które prezentują Harman czy Latour. Ci dwaj filozofowie zwracają się bowiem ku obiektom, podczas gdy Bennett obchodzi nie tyle obiektowość (thinginess) przedmiotów, ile sama ma-

tna, co sprawia wrażenie wspólnoty, pewnego pokrewieństwa między tymi myślicielami. Jednakże, jak pisze Graham Harman, gdy filozofów tych (Graham oprócz Deleuze'a i Latoura wymienia jeszcze między innymi Alfreda Whiteheada, Williama Jamesa, Henriego Bergsona, Isabelle Stengers) „określa się takimi mylącymi nazwami jak »filozofia procesu« czy »filozofia immanencji«, rodzi to fałszywe wrażenie bitnikowskiego braterstwa. A tymczasem pomiędzy osobami z powyższej listy toczy się poważny, rodzinny spór dotyczący bardzo klasycznego problemu — odrębności poszczególnych rzeczy i powiązań między nimi. Po jednej stronie sytuują się postacie takie jak Bergson i Deleuze, według których powszechne stawanie się poprzedza jakąkolwiek krystalizację w jednostkowe byty. Po drugiej stronie stoją autorzy tacy jak Whitehead i Latour, których zdaniem byty są tak konkretne, że momentalnie znikają przy najmniejszej zmianie którejkolwiek z ich własności. Dla pierwszej grupy substancja jest zbyt określona, by mogła być realna, a dla drugiej jest zbyt nieokreślona, by mogła być realna" - idem, Ksiąze sieci..., s. 14-15. Kwestia jest oczywiście całkowicie nierozstrzygalna, co więcej przypomina nieco uparte próby przełamania zasady nieoznaczoności Heisenberga. Na szczęście opowiadanie się po którejś ze stron tego rodzinnego sporu nie jest niezbędne do myślenia o nekrosferze w kategoriach ekokrytycznych. Co więcej, zaakceptowanie jednego poglądu i odrzucenie drugiego skutkowałoby zignorowaniem połowy zagadnień. Dlatego zachowywać będę niepewną neutralność, lawirując pomiędzy dwiema skłóconymi frakcjami.

51 Zob. R. Braidotti, op. cit., s. 132.

52 Jej projekt oczywiście sytuuje się w ramach politycznego zaangażowania, jak każda odmiana ekologii zresztą, dlatego też jej książka nosi podtytuł A Political Ecology of Things. Autorka argumentuje, że teoria polityczna wymaga włączenia w swoje granice namysłu nad aktywnym udziałem nie-ludzkich, też nie-ożywionych, aktorów w wydarzeniach społecznych i politycznych. Na poparcie swoich tez Bennett przywołuje obserwacje, jakie poczynił Darwin na temat robaków w Formation of Vegetable Mould through the Actions of Worms with Observations on Their Habists (1881), gdzie przekonywał, że „robaki odegrały znacznie większą rolę w historii świata niż większość osób byłaby skłonna sądzić" - Ch. Darwin, The Formation of Vegetable Mould, through the Action of Worms, with Observations on Their Habits, London 1881, s. 305, cyt. za: J. Bennett, Vibrant Matter..., s. 95.

53 J. Bennett, Vibrant Matter..., s. 96. 
terialność ${ }^{54}$. Autorka argumentuje także, że figura „rzeczy”, „obiektu” sugeruje indywidualną sprawczość, podczas gdy aktor nigdy nie działa samotnie: „Jego skuteczność czy sprawczość zawsze polega na kolaboracji, kooperacji lub interaktywnych ingerencjach wielu ciał i sił" ${ }^{\prime 5}$.

Mając w pamięci przytoczone koncepcje filozoficzne, można zauważyć, że status irigochi, lecz także samych transformerów w opowiadaniu Dukaja akcentuje kondycję bycia kolektywem, asamblażem. Starość aksolotla przeczytana w zaproponowany tu sposób wpisuje się w posthumanistyczny nurt kwestionujący centralną pozycję człowieka, obdzierający go z jego autonomii i włączający w niehierarchiczne sieci relacji. Uwidacznia, że — jak pisze Bennett — „wiele zmienia się w koncepcji sprawczości, kiedy nie-ludzkie rzeczy postrzegane są mniej w kategoriach konstrukcji społecznych, a bardziej jako aktorzy, a ludzie jako byty nieautonomiczne" $" 56$.

$$
* * *
$$

Konfrontując się ze światem po ekocydzie, Grześ zostaje niejako zmuszony do zmierzenia się z nowym porządkiem bytów, nową hierarchią albo jej brakiem. Świadomość, którą musi uzyskać bohater, jest w gruncie rzeczy świadomością ekologiczną, myśleniem planetarnym, a jak twierdzi Timothy Morton, wiąże się

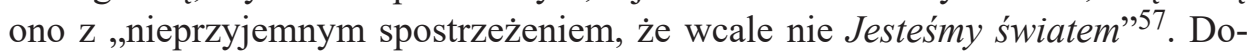
datkowo Grześ staje przed zadaniem pomyślenia siebie, jako przedmiotu, jako asamblażu, co wiąże się także ze zrozumieniem swojej przedmiotowej egzystencji. Być może jednak prawdziwie posthumanistyczne stanowisko polegałoby na zaakceptowaniu niedostępności odpowiedzi, tak jak u Lema załoga Niezwyciężonego musiała ostatecznie pogodzić się z całkowitą obcością nekrosfery.

Co więc wynika z ekologicznego czytania Starości aksolotla i takiego podejścia do nekrosfery? Jaka jest stawka? Oczywiście etyczna, a zatem polityczna ${ }^{58}$. Celem ekologii i ekokrytyki odwołującej się do OO jest przekroczenie antagonistycznych dualizmów człowiek-świat i natura-kultura ${ }^{59}$.

54 Ujmowana na sposób wyraźnie spinozjański jako intensywność i rozciągłość - ibidem, s. 20.

55 Ibidem, s. 21.

56 Ibidem.

57 T. Morton, Hyperobjects. Philosophy and Ecology after the End of the World, Minneapolis-London 2013, s. 99. Morton nawiązuje tutaj do piosenki We Are the World nagranej przez United Support of Artists For Africa (USA for Africa) w celach charytatywnych.

58 Nawiązuję tutaj do pojęcia „polityczności”, nie ,ppolityki”, zgodnie z teorią Chantal Mouffe; zob. eadem, Polityczność, przeł. J. Erbel, Warszawa 2008; eadem, Agonistyka. Polityczne myślenie o świecie, przeł. B. Szelewa, Warszawa 2015.

59 Zob. G. Czemiel, Tajemniczy świat przedmiotów. Autonomia rzeczywistości w spekulatywnym realizmie Grahama Harmana i powojennej poezji polskiej, [w:] Po humanizmie... Zgodnie z tym, co twierdzi Ian Bogost, nie wystarczy objąć granicami demokracji bytów jedynie biosfery 
Powieść Lema Niezwyciężony wyprzedzała tak pojętą refleksję dojrzałego posthumanizu, a Starość aksolotla pojawiła się ${ }^{60} \mathrm{w}$ momencie, kiedy taki nurt w refleksji filozoficznej zyskuje coraz większą popularność i problematyzuje podstawowe jego tematy. Nawiązując do stylistyki Iana Bogosta, można rzec, że żyjemy pośród obcych, różnych od nas w nie mniejszym stopniu niż cytoplazmatyczny ocean pokrywający powierzchnię planety Solaris. Lecz — i to być może jedna z ważniejszych myśli, jakie wykluły się w umysłach posthumanistów — człowiek również jest nie-ludzki ${ }^{61}$. Jak mówił Morton w rozmowie z Gregiem Lindquistem

Spotkania z nieludzkimi istotami są naznaczone niepokojem, ponieważ nie jestem w stanie sprawdzić zawczasu, z kim mam do czynienia. Muszę po prostu pozwolić im istnieć, co oznacza, że ostatecznie jedną z osób, których istnienie muszę przyjąć, dziwnym trafem, jestem ja sam, ponieważ ja też jestem jedną z tych nieludzkich istot. Muszę zaprzyjaźnić się z moim niepokojem. Na tym właśnie polega świadomość ekologiczna i polityka ${ }^{62}$.

Na koniec chciałbym zwrócić się, co sygnalizowałem wcześniej, w stronę etyki spinozjańskiej w interpretacji Deleuze'a, wedle którego etyka jest e to 1 ogią, skupia się jedynie na kwestii aktywności i bierności bytów w relacyjnej sieci $^{63}$. Problematyzowanie relacji między elementami nekro- i biosfery przedstawione w Starości aksolotla skłania do wyjścia poza etyczny namysł nad bioe-

— prawdziwie posthumanistyczna perspektywa wymaga płaskiej ontologii. W interesie ekologicznych teorii jest również odrzucenie antropocentrycznych twierdzeń. Jak przekonuje Graham Harman, „zamiast twierdzić, że rzeczywistość pozazmysłowa ma swoją podstawę w tym, co pojawia się w świadomości, trzeba zgodzić się z Heideggerem, iż jest wręcz odwrotnie" — idem, Traktat o przedmiotach..., s. 57. Celem takiego posthumanistycznego (i ekologicznego) stanowiska „nie jest ani rozszerzenie podmiotowości na rzeczy, ani robienie z maszyn aktorów społecznych, ale całkowite uniknięcie używania rozróżnienia na podmiot i przedmiot. Wszystko po to, by można było mówić o splataniu ludzi z czynnikami pozaludzkimi” - B. Latour, Nadzieja Pandory..., s. 242). Grzegorz Czemiel słusznie utrzymuje, że zadaniem posthumanizmu jest „problematyzacja statusu ontologicznego człowieka", nawet jeżeli zawsze to on będzie ostatecznym odniesieniem refleksji, w końcu ,nie można całkowicie uciec od własnego centryzmu [...] jako pewnego węzła sieci [...] lub asamblażu tego, co materialne i niematerialne, bez uprzedniego puryfikowania i redukowania tych elementów" - idem, op. cit., s. 188.

${ }^{60}$ Myślę tutaj o pierwotnym wydaniu w formie e-booka, ale oczywiście dotyczy to również wersji drukowanej z 2019 roku.

${ }^{61} \mathrm{Na}$ ten temat zob. R. Braidotti, op. cit.

62 T. Morton, G. Lindquist, Timothy Morton with Greg Lindquist, „The Brooklyn Rail”, http:// www.brooklynrail.org/2013/11/art_books/timothy-morton-with-greg-lindquist (dostęp: 5.09.2016), cyt. za: G. Czemiel, op. cit., s. 189.

63 Jak czytamy u Deleuze'a, spinozjańska etyka jest etologią, ,rozpatrując człowieka i zwierzęta, w każdym przypadku bierze pod uwagę jedynie ich zdolność oddziaływania i bycia poddanym oddziaływaniom" - idem, Spinoza: Practical Philosophy, przeł. R. Hurley, San Francisco 1988, s. 27 (korzystam tutaj z przekładu Żylińskiej — eadem, op. cit., s. 54). W przekładzie Jędrzeja Brzezińskiego przytaczany fragment brzmi następująco: „Etyka natomiast — będąc etologią — zarówno ludzi, jak i zwierzęta określa jedynie według ich zdolności bycia pobudzanymi” — G. Deleuze, Spinoza. Filozofia praktyczna, przeł. J Brzeziński, Warszawa 2014, s. 44. Przekład Brzezińskiego jest bliższy tłumaczeniu angielskiemu i oryginałowi, jednak wersja Żylińskiej lepiej oddaje ideę „bycia pobudzanymi”, ponieważ — jak pisze dalej Deleuze — „Zdolność bycia pobudzanym jawi 
tyką i objęcie nim również obiektów nieorganicznych, gdyż w procesie tworzenia sieci, aktora-sieci, wchodzą w relacje między sobą elementy żywe i nie-żywe ${ }^{64}$, będące różnymi formami wibrującej materii, co wymaga sięgnięcia po nie-ludzką etykę Deleuze'a, która wykracza poza paradygmat dobra i zła, pragmatycznie skupiając się na relacjach między aktorami. Dobro — zdaniem Deleuze'a — pojawia się wtedy, gdy jakieś ciało łączy się w relacji z naszym, zwiększając jego moc, potencjalność. Dochodzi więc do decentralizacji podmiotu przez wskazanie, że $\mathrm{w}$ istocie jest on zarówno aktorem-siecią, jak i elementem sieci, i tylko w ekosystemie może się stawać. Uznanie, że „człowiek istnieje zawsze w powiązaniu z innymi żywymi i nie-żywymi”"65 ciałami, a także że samo życie nie jest „w”, ale „pomiędzy”, stwarza się i rozwija w połączeniach, wyznacza drogę nie tylko dla (bio)etyki, lecz także dla nie-ludzkiej ekologii i ekopolityki, dla których podstawowym wyzwaniem jest przemyślenie sposobów funkcjonowania w relacyjnej, hybrydycznej sieci.

\section{Bibliografia}

\section{Teksty}

Dukaj J., Starość aksolotla, e-book, Wydawnictwo Literackie, Kraków 2015.

Dukaj J., Starość aksolotla — hardware dreams, Wydawnictwo Literackie, Kraków 2019.

Lem S., Niezwyciężony, Wydawnictwo MON, Warszawa 1964.

\section{Opracowania}

Abram D., Becoming Animal: An Earthly Cosmology, Pantheon Books, New York 2010.

Alaimo S., Bodily Natures Science, Environment, and the Material Self, Indiana University Press, Bloomington 2010.

Abriszewski K., Czy Teoria Aktora-Sieci daje narzędzia do ekokrytyki?, „Teksty Drugie” 2018, nr 2, s. 369-391.

Barad K., Meeting the Universe Halfway: Quantum Physics and the Entanglement of Matter and Meaning, Duke University Press, London 2007.

Barcz A., Przedmioty ekozagłady. Spekulatywna teoria hiperobiektów Timothy'ego Mortona i jej (możliwe) ślady w literaturze, „Teksty Drugie” 2018, nr 2, s. 75-87.

Bednarek J., Życie, które mówi. Nowoczesna wspólnota i zwierzęta, Wydawnictwo PWN, Warszawa 2017.

Bennett J., The Enchantment of Modern Life: Attachments, Crossings, and Ethics, Princeton University Press, New York 2001.

Bennett J., Vibrant Matter. A Political Ecology of Things, Duke University Press, London 2010.

Braidotti R., Po człowieku, przeł. J. Bednarek, A. Kowalczyk, Wydawnictwo PWN, Warszawa 2014.

się więc jako moc działania, o ile spełnia się przez pobudzenia czynne, ale także jako zdolność doznaw ania, o ile jest spełniana przez pobudzenia" — ibidem.

${ }^{64}$ Zob. J. Żylińska, op. cit., s. 54.

65 Ibidem, s. 56. 
Coole D., Frost S., New Materialisms: Ontology, Agency, and Politics, Duke University Press, London 2010.

Czemiel G., Tajemniczy świat przedmiotów. Autonomia rzeczywistości w spekulatywnym realizmie Grahama Harmana i powojennej poezji polskiej, [w:] Po humanizmie. Od technokrytyki do animal studies, red. Z. Ładyga, J. Włodarczyk, Wydawnictwo Naukowe Katedra, Gdańsk 2015, s. $156-190$.

Davis E., TechGnoza. Mit magia + mistycyzm w wieku informacji, przeł. J. Kierul, Poznań 2002.

DeLanda M., Intensive Science \& Virtual Philosophy, London-New York 2002.

Deleuze G., Immanencja: życie, przeł. K.M. Jaksander, Wydawnictwo Eperons-Ostrogi, Kraków 2017.

Deleuze G., Spinoza. Filozofia praktyczna, przeł. J Brzeziński, Wydawnictwo PWN, Warszawa 2014.

Harman G., Ksiażę sieci. Bruno Latour i metafizyka, przeł. G. Czemiel, M. Rychter, Fundacja Augusta hr. Cieszkowskiego, Warszawa 2016.

Harman G., Traktat o przedmiotach, przeł. M. Rychter, Wydawnictwo Naukowe PWN, Warszawa 2013.

Harraway D., The Companion Species Manifesto: Dogs, People, and Significant Otherness, Prickly Paradigm Press, Chicago 2003.

Harraway D., When Species Meet, University of Minnesota Press, Minneapolis 2008.

Hekman S., The Material of Knowledge Feminist Disclosures, Indiana University Press, Bloomington 2010.

Iovino S., Oppermann S., Material Ecocriticism, Indiana University Press, Bloomington 2014.

Jankowicz G., Smutek robotów (Jacek Dukaj), [w:] idem, Uchodźcy z ziemi Urlo. Eseje, Wydawnictwo EMG, Kraków 2015, s. 227-232.

Kirby V., Quantum Anthropologies: Life at Large, Duke University Press, London 2011.

Latour B., Nadzieja Pandory. Eseje o rzeczywistości w studiach nad nauka, przeł. K. Abriszewski et al., Wydawnictwo UMK, Toruń 2013.

Latour B., Nigdy nie byliśmy nowocześni, przeł. M. Gdula, Oficyna Naukowa, Warszawa 2011.

Latour B., Splatajac na nowo to, co społeczne. Wprowadzenie do teorii aktora-sieci, przeł. A. Derra, K. Abriszewski, Universitas, Kraków 2010.

Latour B., The Pasteuruzation of France, przeł. A. Sheridan, J. Law, Harvard University Press, Cambridge, MA 1988.

Lem S., Summa technologiae, Wydawnictwo Agora, Warszawa 2010.

Małecki W., Rzeczy maja głos: realizm spekulatywny i literaturoznawstwo, [w:] Współczesne dyskursy konfliktu. Literatura - język - kultura, red. W. Bolecki, W. Soliński, M. Gorczyński, Wydawnictwo IBL, Warszawa 2015.

Marzec A., „Jesteśmy połaczonym ze sobą światem” - Timothy Morton i widmo innej wspólnoty, „Teksty Drugie” 2018, nr 2, s. 88-102.

Massumi B., Autonomia afektu, przeł. A. Lipszyc, „Teksty Drugie” 2013, nr 6, s. 112-135.

Mathews F., For Love of Matter: A Contemporary Panpsychism, SUNY Press, New York 2003.

Morton T., Hyperobjects. Philosophy and Ecology after the End of the World, University of Minnesota Press, Minneapolis-London 2013.

Morton T., Queer ecology, „Publications of the Modern Language Association” 2010, nr 2, s. 273 282.

Mouffe Ch., Agonistyka. Polityczne myślenie o świecie, przeł. B. Szelewa, Warszawa 2015.

Mouffe Ch., Polityczność, przeł. J. Erbel, Warszawa 2008.

Nowak A.W., Wyobraźnia ontologiczna. Filozoficzna (re)konstrukcja fronetycznych nauk społecznych, Wydawnictwo IBL, Wydawnictwo Naukowe UAM, Warszawa 2016.

Pacewicz K., Fluks. Wspólnota płynów ustrojowych, Wydawnictwo PWN, Warszawa 2017. 
Pickering A., The Mangle of Practice. Time, Agency, and Science, The University of Chicago Press, Chicago 1995.

Poetyki ekocydu. Historia, natura, konflikt, red. A. Ubertowska, D. Korczyńska-Partyka, E. Kuliś, Wydawnictwo IBL, Warszawa 2019.

Rouse J., How Scientific Practices Matter: Reclaiming Philosophical Naturalism, The University of Chicago Press, Chicago 2002.

Słotwińska K., Bernard Stiegler: wynalazek człowieka, czyli filozofia wobec wspótczesności, [w:] Po humanizmie. Od technokrytyki do animal studies, red. Z. Ładyga, J. Włodarczyk, Wydawnictwo Naukowe Katedra, Gdańsk 2015, s. 260-284.

Stiegler B., Technics and Time 1: The Fault of Epimetheus, przeł. R. Beardsworth, G. Collins, Stanford University Press, Stanford 1998.

Stiegler B., Technics and Time 3: Cinematic Time and the Question of Malaise, przeł. S. Barker, Stanford University Press, Stanford 2011.

Ubertowska A., Natura u kresu (ekocyd). Podmiotowość po katastrofie, „Teksty Drugie” 2013, nr 1-2, s. 33-44.

Uniłowski K., Lord Dukaj albo fantasta wobec mainstreamu, „FA-art.” 2007, s. 36-43.

Wróbel S., Przedmowa do polskiego wydania. Otchłań przedmiotu. O filozofii, która nie jest już strażniczka bytu, [w:] G. Harman, Traktat o przedmiotach, przeł. M. Rychter, Wydawnictwo Naukowe PWN, Warszawa 2013, s. XVIII.

Żylińska J., Bioetyka w epoce nowych mediów, przeł. P. Poniatowska, Wydawnictwo IBL, Warszawa 2013.

\title{
Źródla internetowe
}

Małecki W., „World Literature Today” 2014, nr 3, http://www.worldliteraturetoday.org/2014/may-august/booklist-international-environmental-literature-part-2 (dostęp: 22.08.2016).

Morton T., Lindquist G., Timothy Morton with Greg Lindquist, „The Brooklyn Rail”, http://www. brooklynrail.org/2013/11/art_books/timothy-morton-with-greg-lindquist (dostęp: 5.09.2016).

Robaczewski G., Odczytywanie światów Jacka Dukaja. „Esensja” 2004, nr 1, https://esensja.pl/ ksiazka/publicystyka/tekst.html?id=326 (dostęp: 5.09.2016).

\section{Life after life or the republic of beings: Jacek Dukaj's Starość aksolotla [Senility of Axolotl] in ecocritical perspective}

\author{
Summary
}

In the presented article, the author explores the possibilities of an ecocritical reading of the Starość aksolotla by Jacek Dukaj. Particular emphasis is placed on the post-humanist motifs and implications of the story. At the same time, the author extensively discusses the latest trends in ecocriticism and tries to supplement the interpretation of the literary text with theoretical reflections on the situation, challenges and future of ecocriticism. The author also presents the possibilities of using such trends as new materialism, flat ontology or Actor-Network Theory in ecocritical practice. The most important theoretical contexts are Bernard Stiegler's reflections on the nature of technology, Latour's Actor-Network Theory reinterpreted by Graham Harman, Jane Bennett's new materialism and "ecology without nature" of Timothy Morton. 